Article Type: Research Paper

\title{
The Determinants of Meat Import Performance in ASEAN Countries
}

\author{
Adelia Erlita Putri ${ }^{1}$, Endang Sulistiyani ${ }^{2 *}$, and Febrina Indrasari ${ }^{3}$
}

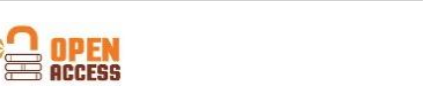

AFFILIATION:

1,2,3 Department of Business

Administration, Politeknik Negeri

Semarang, Central Java, Indonesia

*CORRESPONDENCE:

endangsulis15@polines.ac.id

THIS ARTICLE IS AVAILABLE IN:

http://journal.umy.ac.id/index.php/mb

DOI: $10.18196 / \mathrm{mb} . v 12 \mathrm{i} 1.10636$

\section{CITATION:}

Putri, A.E., Sulistiyani, E., \&

Indrasari, F. (2021). The

Determinants of Meat Import

Performance in ASEAN Countries.

Jurnal Manajemen Bisnis, 12(1), 88-100.

\section{ARTICLE HISTORY}

Received:

19 Dec 2020

Revised:

09 Feb 2021

24 Feb 2020

Accepted:

03 Mar 2021

\begin{abstract}
:
Research aims: The objective of this research is to analyze the effect of Gross Domestic Product, exchange rate, and distance on the meat import performance of ASEAN countries both partially and simultaneously.

Design/Methodology/Approach: Purposive sampling method was adopted to determine the research sample. The data used were the annual secondary data of ASEAN countries in the period of 2012-2018, collected from trademap.org, World Bank, and macmap.org. Multiple Linear Regression was employed to analyze the data.

Research findings: The regression analysis results showed that GDP and exchange rate did not affect meat import performance. Meanwhile, distance had a partially significant negative effect on meat import. However, GDP, exchange rate, and distance had a significant effect on meat imports simultaneously. Theoretical contribution: Previous researchers have used economic distance in their study to see its impact on imports. Nevertheless, there has not been much research done using geographical distance as an antecedent variable. The distant market has to incur large-fixed costs, which can only be supported if the export value is large. The negative impact of distance on imported meat must be taken seriously. AANZFTA supposedly gives a contribution to the member countries thoroughly to export goods and services. It is to increase per capita income so that it can be used to improve the transportation system.

Implication policy: ASEAN officials are suggested to encourage the member countries to provide better transportation facilities to eliminate geographical distance barriers and further support SMEs and other business actors' engagement. Due to the limitation of this research, it is suggested that further research should consider using other commodities to measure the import performance.

Keywords: Gross Domestic Product; Exchange Rate; Distance; Meat Import
\end{abstract}

\section{Introduction}

According to Krugman, Obstfeld, and Melitz (2018), countries engage in international trade for two fundamental reasons, each of which contributes to their trade gain. First, countries trade because they are different from each other. Nations, like individuals, can benefit from their differences by reaching an arrangement in which each does things relatively well. Second, countries trade to achieve economic scales in production. If each country produces only a limited range of goods, it can produce each of these goods at a larger scale and hence more efficiently than if it tries to produce all of them. 
This mutual need encourages many countries to establish a form of cooperation such as regional organizations like ASEAN (Association of Southeast Asian Nations). This international organization was formed to achieve the objectives of member countries' interests in terms of economic, social, cultural, etc.

In terms of economic, ASEAN's formation has led to the elimination of the barrier of economic activity over the past five decades. It is substantial in the globalization era, where each country is expected to conduct trade and open economy. With the existence of regional economic cooperation, it is aimed at increasing ASEAN economic growth.

ASEAN has been putting efforts through establishing Free Trade Agreement (FTA) with a partnering country. One of the most comprehensive FTAs that ASEAN has so far is the ASEAN-Australia-New Zealand Free Trade Agreement (AANZFTA). By signing the AANZFTA, member countries expect an increase in the nation's trade performance.

Regardless, after eight years of implementation, there is still a large gap among ASEAN countries as importers from Australia, as seen in the Table 1.

Table 1 ASEAN imports value from Australia in 2018

\begin{tabular}{cc}
\hline Country & Imports (USD) \\
\hline Singapore & $4,897,330$ \\
Malaysia & $4,560,715$ \\
Viet Nam & $3,723,685$ \\
Indonesia & $4,294,601$ \\
Thailand & $4,840,842$ \\
Philippines & $1,578,101$ \\
Myanmar & 125,836 \\
Cambodia & 42,504 \\
Brunei Darussalam & 38,764 \\
Laos & 20,283 \\
\hline
\end{tabular}

Source: trademap.org, 2020

Based on Table 1, Laos, Brunei Darussalam, Cambodia, and Myanmar had a relatively small amount of import value from Australia. Laos had the smallest import value by USD 20,283 thousand. Conversely, the other six member countries had a quite distinct amount of import value. Singapore led with USD 4,897,330 thousand, which accounted for the enormous gap with the former four countries. Accordingly, the gap of import value among ASEAN member countries from Australia could not be ignored.

During the AANZFTA implementation, one of the commodities that are likely to gain momentum is a meat-based product. Australia and New Zealand initially hold a considerably large market share in South East Asia (SEA). Particularly, Australia accounts for $27 \%$ of the meat import market share in SEA.

In some previous research, a few variables have been observed as the independent variables of import performance. Agung, Ishak, Asngari, and Bashir (2019) researched ASEAN-Korea Free Trade Agreement, who found that GDP had a significant positive effect 
on Indonesian imports. Meanwhile, exchange rate and distance were revealed to be insignificant. Khalimah (2019) examined factors affecting beef imports in Indonesia and uncovered that GDP was insignificant to beef imports. Conversely, the exchange rate was found to be negative and significant.

Hutzschenreuter, Kleindienst, and Lange (2015) investigated several effects of distance dimensions on MNE's international expansion. It was precedented by his former literature review, which provided some clarity and in-depth discussion on distance dimensions. He concluded that geographical distance did have drawbacks as it increased the transportation cost. However, it also had legitimate benefits, namely better decisionmaking. There has not been much research done using distance as an antecedent variable. Moreover, some of the few tended to have different results. Marimoutou, Peguin, and Peguin-Feissolle (2010) studied the behavior of national income and distance to export to the gravity models. The conclusion was that national income had a positive and significant impact on the export, whereas the distance showed a significant and negative effect. Mulyadi, Saenong, and Balaka (2017) used economic distance in his study to see its impact on imports, which resulted that it had a significant effect on imports. He also argued that economic distance is more compatible rather than geographic distance. However, Hutzschenreuter et al. (2015) reasoned that despite having only a few studies that have adopted it, geographic distance should be more widely used in international business studies, where it is well established and has clarity and consistency in its measurement.

Recalling the fluctuation and large gap in ASEAN imports and knowing that no research has used all ASEAN countries as research objects in linking GDP, exchange rates, and distance to meat imports performance, it is necessary to investigate it further. Furthermore, based on the diverse results of previous research, this study attempts to do research utilizing GDP, exchange rate, and distance as the independent variables.

This research aims to find the effect of GDP, exchange rate, and distance on meat import performance in the ASEAN countries from 2012 to 2018. This research's output is expected to be favorable for conducting future trade performance research under ASEAN's framework. Besides, this research is expected to be referenced in consideration of policymaking.

\section{Literature Review and Hypotheses Development}

According to Mankiw (2012), imports are goods and services bought from other countries. In regards to international trade, countries worldwide have been carrying out commerce by exporting the goods they produce to other countries and importing the needed goods from other countries.

Regarding the trade cooperation of ASEAN and Australia, one sector that is likely to gain momentum is the meat-based product. The establishment of AANZFTA sets the basic tariff rates for Australian meat product access to the 10 ASEAN countries. According to Meat and Livestock Australia (MLA) report in 2018, Australian red meat exporters were likely to 
retain favorable trade access to South East Asia until around 2020. It was also mentioned that food and live animals accounted for almost one-third of the 2016 Australian exports to ASEAN, with meat valued at $\$ 730 \mathrm{~m}$.

Sukirno (2015) mentioned the import benefits as follows:

1. Obtaining goods and services that cannot be produced domestically

The diversity of natural sources in each country sets a limitation to producing certain kinds of goods. Specific sources might not be able to be obtained in a particular country. Thus, import becomes a substantial to acquire goods that cannot be self-produced by a country.

\section{Obtaining modern technology}

Developing countries tend to utilize simpler technology than developed countries, which tend to use more sophisticated technology. Import, thus, allows countries to adopt and exchange information regarding their technology.

\section{Obtaining raw material}

The raw material is required in any business activity. However, it is not rare that raw material cannot be purchased or obtained domestically. Therefore, the import will help a country to obtain the raw material for production purposes.

Moreover, Gross Domestic Product (GDP) is the market value of all goods and services produced in a country in a certain period (Mankiw, 2012). The higher GDP per capita will increase the public consumption pattern of meat to affect imported goods' value (Puspita, 2018). Supposed there is an increase in national income (GDP), the consumption of goods will follow accordingly and most likely will reflect an increased demand for foreign goods (Madura, 2012). An increase in national income (GDP) will increase people's purchasing power of import on the one hand, and on the other hand, an increase in national income will also increase the community's ability to carry out production processes that can ultimately be exported to other countries (Adi, 2017). According to Fitzsimons, Hogan, and Neary (1999), increasing the GDP per capita of the importing country will increase the country's consumption, so that the demand for imports will also increase. It is also believed in Adam Smith's theory that income will influence import; the higher the income, the more a country will import (Salvatore, 2014). Therefore, GDP in this study is considered as a factor affecting imports.

\section{$H_{a 1}:$ Gross Domestic Product affects meat import.}

In international business, the relationship between imports and exchange rates are two things that cannot be separated. Exchange rates are vital in international payment transactions, one of which is the US dollar exchange rate. Mankiw (2012) explained that if the exchange rates are low, domestics goods are relatively cheap; thus, imports will be 
fewer, and export demand will be high. Likewise, the opposite will occur if the exchange rate is high; thus, imports demand will be higher, while exports will be fewer.

According to Salvatore (2014), in the Mundell-Fleming Model theory, fluctuations in the value of a country's currency against another country will result in changes in the direction of exports and imports between these countries. Adi (2017) said that there was a negative relationship between the exchange rate against the US dollar with imports, meaning that an increase in the exchange rate would reduce imports. Based on Mankiw (2012), if the exchange rate of the importing country against the exporting country experiences a depreciation, it will reduce the incentive to import because the price of the product of the importing country is more competitive. Therefore, the exchange rate in this study is considered as a factor affecting imports.

\section{$H_{a 2}:$ Exchange rate affects meat import.}

According to Beckerman in Hutzchenreuter et al. (2014), it has been argued that geographic distance is an indicator of trade resistance due to its association with transportation and communication costs. However, because of the significant development in transportation and communication technology throughout decades, the cost associated with geographic distance has been reduced. Nonetheless, geographic distance is directly related to transportation and communication costs, which are associated with cross-border business.

Furthermore, geographic distance refers to the physical separation between two countries. It is usually measured the distance from each capital city or the biggest city in the country. Despite being well established in the international trade literature, only a few adoptions of the geographic distance concept dated back more than half a century. It is said that the most prominently used approach to measure geographic distance is the one based on a great circle distance formula between capitals or major cities (Hutzschenreuter, Kleindienst, \& Lange, 2014). According to Li, Song, and Zhao (2008), geographical distance is also used to represent transportation costs through the following formula:

$$
\text { Distance }=\text { Geographical distance } x \frac{\sum G D P}{G D P}
$$

The distance is measured through the geographical distance between importing and exporting countries multiplied by the GDP of importing countries. Despite only a few studies examining the performance effect of distance dimension other than cultural distance, Hutzschenreuter et al. (2014) argued that distance would negatively affect international business performance. It has been argued in the International Trade literature that distance is an indicator of trade resistance (Beckerman, 1956).

Thus, considering those mentioned, this research adopts geographical distance as the base concept of distance dimensions and transportation cost representation.

$H_{a 3}$ : Distance affects meat import. 
In the theory of the Mundell-Fleming Model in Salvatore (2014), it was stated that fluctuations in the value of a country's currency against another country would result in changes in the direction of exports and imports between these countries. According to Salvatore (2014), in Adam Smith's theory, it is believed that income would influence import; the higher the income, the more a country would import. Marimoutou et al. (2010) mentioned that the larger the partner's GDP, the less the distance's effect on trade. It supports the hypothesis that GDP and distance can have a significant effect. Besides, Anggiani and Azizah (2019) found that GDP and exchange rate significantly affected beef imports. Pakpahan (2012) disclosed that GDP and exchange rate significantly impacted beef imports. Research conducted by Agus and Ayuningsasi (2016) also revealed a significant influence between the US dollar exchange rate and GDP on Australian beef imports, stating that GDP and Rupiah exchange rates influenced the imported beef value in Indonesia. Therefore, the following hypothesis was obtained.

$H_{a 4}:$ Gross Domestic Product, exchange rate, and distance affect meat import.

According to the hypothesis development, therefore, the theoretical framework was formulated as follows.

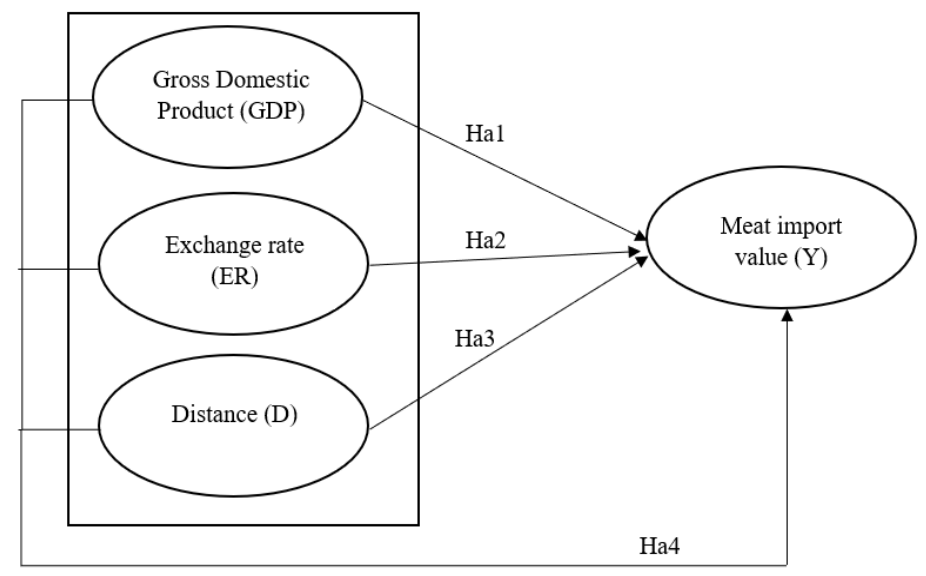

Figure 1 Theoretical framework

Source: Mulyadi et al. (2017); Hutzschenreuter et al (2015), further developed for this study, 2020

\section{Research Methods}

This explanatory research explained the position of the variables studied and the effect of one of the variables on other variables. It was conducted through a quantitative research method to observe a specific population or sample employing quantitative data analysis/ statistical, aiming to test the determined hypothesis. This study's object was the effect of GDP, exchange rate, and distance on the meat imports of ASEAN countries from Australia during the period of 2012-2018, in which the data were acquired from the Trade map. 


\section{Population and Sample}

The population in this research was derived from the data of imports. The sample was based on purposive sampling, determined by specific criteria. The criteria are as follows:

1. Annual data of import

2. Period of 2012-2018

3. Meat import data of ASEAN countries from Australia

4. GDP of ASEAN countries

5. Exchange rate of ASEAN countries

6. Distance from Australia to ASEAN countries

Based on the criteria, a total of 7 years of annual data on the period of 2012-2018 from 10 ASEAN member countries was acquired.

\section{Data Collecting Method}

The data used in this research were secondary data obtained through the documentation method. The data were obtained from several sources, such as but not limited to trademap.org, worldbank.org, and macmap.org.

\section{Data Analysis Technique}

This research employed descriptive analysis and regression analysis, consisting of classical assumption and multiple linear regression tests. The method of multiple linear regression aimed to find out how the relationship between the dependent variable and the independent variables through Coefficient determination $\left(R^{2}\right)$, Simultaneous test (F-test), and Partial test (T-test).

\section{Results and Discussion}

\section{Descriptive Statistics}

This analysis used the descriptive statistics method, transforming raw data to be easier to understand and interpret, rearranging, ordering, and manipulating data to generate descriptive information (Zickmund, 2003). The descriptive statistics output Table 2.

Table 2 Descriptive statistics output

\begin{tabular}{lccc} 
& Min. & Max. & Mean \\
\hline GDP & 950.88 & 64581.94 & 12432.1617 \\
Exchange Rate & 0.000044 & 0.800277 & 0.18443307 \\
Distance & 13014.83 & 1736164.65 & 390617.880 \\
Meat Import & 82 & 565069 & 144981.76 \\
Valid N (listwise) & & & \\
\hline
\end{tabular}

Source: Data Processing Output (2020) 
Table 2 shows that the GDP variable had the lowest value on Cambodia's GDP in 2012 at 950.88, and the highest was on Singapore's GDP in 2018 at 64581.94, with an average value of 12432.1617. On the other hand, the exchange rate hit bottom on Vietnam's exchange rate in 2018 at 0.000044 , while the peak was on Brunei's exchange rate in 2013 at 0.800277 , with an average value of 0.18443307 . Meanwhile, the lowest data of distance was 13014.83, which was the distance of Indonesia to Australia in 2012 and peaked at 1736164.65, which was the distance of Laos to Australia in 2012, with an average of 390617.880. Further, meat import had the lowest value on Lao PDR in 2014 at 82 , and the highest was on Indonesia's in 2018 at 565069, with average data of 144381.76.

\section{Determination Coefficient and F-Test}

According to Ghozali (2016), the Coefficient of Determination $\left(R^{2}\right)$ test is performed to explain the magnitude of the independent proportions that affect the dependent variable. The $\mathrm{R}^{2}$ test also aims to measure how well the regression lines are formed.

F-test is conducted to determine the overall independent variable's effect on the dependent variable (Ghozali, 2016). In this study, the F-test was used to determine the effect of GDP, exchange rate, and geographical distance on meat import. The output of the determination coefficient and the F-test results in Table 3.

Table 3 Determination coefficient and F-test results

\begin{tabular}{ccccc}
\hline & Model & Adjusted R Square & $F$ & Sig. \\
\hline 1 & Regression & .485 & 30.628 & $.000^{\mathrm{b}}$ \\
\hline
\end{tabular}

Source: Data Processing Output (2020)

Based on the Table 3, the adjusted $R$ square value was 0.485 , meaning that GDP per capita, exchange rates, and distance influenced $48.5 \%$ on the meat import value. Meanwhile, the remaining $51.5 \%$ was influenced by other variables not observed in this study.

From the ANOVA test or F-test, the calculated F-value was 30.628 , with a probability of 0.000 . Because the probability was much smaller than 0.05 , it indicated that the regression model could be used to predict meat import value. It signified that GDP, exchange rate, and distance simultaneously influenced meat import value.

\section{Regression Test Results}

Multiple regression was employed to analyze the relationship between variables in this study to analyze the factors affecting meat imports in ASEAN countries in 2012-2018. The multiple regression analysis results in Table 4. 
Putri, Sulistiyani, \& Indrasari

The Determinants of Meat Import Performance in ASEAN Countries

Table 4 Results of regression test

\begin{tabular}{|c|c|c|c|c|}
\hline \multicolumn{5}{|c|}{ Coefficients } \\
\hline \multicolumn{2}{|c|}{ Model } & Unstandardized Coefficient & $\mathrm{t}$ & Sig \\
\hline \multirow[t]{4}{*}{1} & (Constant) & 815266.551 & 1.767 & .083 \\
\hline & GDP & 24906.441 & .657 & .514 \\
\hline & Exchange Rate & 10732.978 & 1.286 & .204 \\
\hline & Distance & -66762.848 & -4.380 & .000 \\
\hline
\end{tabular}

Based on the multi regression result, SPSS calculation, the following regression models were obtained, as follows:

$$
Y=815,266+24,906.441 G D P+10,732.978 E R-66,762.848 D
$$

$\mathrm{Y} \quad=$ Meat import value (US\$)

GDP = Gross Domestic Product per capita (US\$)

ER = Exchange rate (US\$/LCU)

D $\quad$ Distance

T-test was also conducted to partially determine the effect of independent variables on the dependent variable (Ghozali, 2016). Based on Table 4, the hypotheses' testing results were obtained, as follows:

1. The sig value of GDP per capita was 0.514 , which was higher than 0.05 . Therefore, $\mathrm{HO}_{1}$ was accepted, and $\mathrm{Ha}_{1}$ was rejected. Thus, it could be concluded that GDP had an insignificant effect on meat import.

2. Based on the Table 4, the sig value of the exchange rate was 0.204 , higher than 0.05 . It denoted that $\mathrm{HO}_{2}$ was accepted, and $\mathrm{Ha}_{2}$ was rejected. In that light, it could be said that the exchange rate had an insignificant effect on meat import.

3. The Table 4 displays the sig value of the distance of 0.000 , greater than 0.05 . It indicated that $\mathrm{HO}_{3}$ was rejected, and $\mathrm{Ha}_{3}$ was accepted. Thus, the conclusion is that distance had a significant effect on meat import.

In accordance with the direction of the regression coefficient and partial test (t-test) of the independent variable to dependent variable, it could be concluded that distance had a significant negative effect on meat import.

\section{Discussion}

GDP was found to have an insignificant effect on meat import value. Having the sig value of 0.514 , which was less than 0.05 , brought the conclusion of rejecting Hypothesis a1. This result is contrary to the previous research and theories that found that GDP significantly affected imports (Adi, 2017; Agung et al., 2019). Regardless, this result is according to previous findings that stated that GDP had an insignificant effect on imports (Dewi, 2018; Khalimah, 2019). 
Looking at each country's condition per se, some countries had a considerably low meat import value from Australia. For instance, despite having high GDP, Brunei had a relatively low meat import value from Australia. After being explored, it was found that Brunei had two other major suppliers for imported meat from 2012 to 2018 (Trademap.org, 2020), namely India and Malaysia. It was also the case with Lao PDR, which had the largest meat supplier from Thailand between 2012 and 2018 (Trademap.org, 2020). It might explain the insignificant effect of GDP on meat import from Australia to ASEAN countries.

Similar to GDP, the test results on the exchange rate effect on meat import value showed that it did have an insignificant effect. The outcome revealed a significant value of the exchange rate variable of 0.204 , greater than 0.05 . Hence, it was concluded that $\mathrm{Ha}_{2}$ was rejected. This result is not in line with the preceding research conducted by Yuliadi in Adi (2017) and Prafajarika, Yulianto, Wilopo (2016), which exposed that the exchange rate had a significant effect on importing. However, Junaidi, Sulasmiyati, and Nurlaily (2018) and Ichsan, Suhadak, \& Sulasmiyati (2016), on the contrary, found that the exchange rate did not have a significant effect on imports.

Further, the exchange rate's insignificancy to import in this research explained that the ASEAN countries' movement rate is not the main influencing factor of meat import. Madura (2012) justified that the most influential factors of international trade are inflation, national income, government policies, and exchange rates.

Meanwhile, the variable of distance had a sig value of 0.000 , less than 0.05 . That outcome indicated that hypothesis a3 was accepted, which signified that meat import value was influenced by geographical distance. The outcome aligns with the notion of Hutzschenreuter et al. (2014), which argued that geographic distance would have a negative effect on international business performance.

As a matter of fact, Australia is considered as a relatively close neighboring country in terms of geographical distance to ASEAN countries. However, countries in the furthest north part of ASEAN like Myanmar and Lao PDR might not be relying on the Australian market as much as other member countries. These countries might prefer to choose closer exporting meat country like India.

On the other hand, the finding contrasts with Marimoutou et al. (2010), who found that distance had a significant negative effect on trade. The explanation to the finding was associated with transportation cost as a fixed cost in exports and imports. It was explained that a distant market had to incur a large-fixed cost, which could only be supported if the export value was large. Meanwhile, as a closer market would have a lower fixed cost, the exporter could trade a smaller value, thus serving smaller markets.

Based on the F-test result, it was concluded that GDP, exchange rate, and distance had a significant effect on meat imports simultaneously. With the sig value of 0.000 , which was higher than 0.05 , hypothesis a4 was accepted. This result indicated that this regression model could be utilized to predict meat import as the dependent variable. The result is in 
accordance with the preceding that GDP and exchange rate had a significant effect on beef imports simultaneously (Anggiani \& Azizah, 2019; Pakpahan, 2012)

Marimoutou et al. (2010) mentioned that the larger the partner's GDP, the less the distance's effect on trade. It explained why GDP, exchange rate, and geographical distance could have a significant effect simultaneously even though GDP had an insignificant effect partially. Thus, it strengthened the argument that GDP, exchange rate, and geographical distance were found to have a significant effect on meat import simultaneously.

\section{Conclusion}

The ASEAN meat import value from Australia was determined by GDP per capita, exchange rate, and geographical distance as much as $48.5 \%$. It denoted that only $61.5 \%$ was determined by other variables not examined in this study.

GDP, exchange rate, and distance were found to be significantly influencing meat imports simultaneously. However, partially, only distance had a significant effect. Meanwhile, GDP and exchange rate remained insignificant to the meat import. According to the coefficient value, the distance was concluded to be the most influential variable as it had the highest number of coefficients.

Based on this research's results, the following suggestions are proposed: (1) According to the research's results, the adjusted $\mathrm{R}$ square value was $48.5 \%$. Therefore, the remaining $61.5 \%$ was a variable that could be included in the model to predict meat import. Among them are tariff and trade policy (Agung et al., 2019). (2) The sample was used only in ASEAN countries. Further research is recommended to utilize more samples of the countries, which have trade cooperation with Australia.

\section{References}

Adi, L. (2017). Pengaruh exchange rate dan GDP terhadap ekspor dan impor Indonesia. Develop, 1(1), 1-16. https://doi.org/10.25139/dev.v1i1.69

Agung, A. S., Ishak, Z., Asngari, I., \& Bashir, A. (2019). The effect of ASEAN-Korea Free Trade Agreement (AKFTA) on Indonesia trade: A gravity model approach. Jurnal Ekonomi Pembangunan, 17(1), 1-7. https://doi.org/10.29259/jep.v17i1.8916

Agus, I. M. D., \& Ayuningsasi, A. A. K. (2016). Pengaruh kurs, harga, dan PDB terhadap impor sapi Australia ke Indonesia. E-Jurnal Ekonomi Pembangunan Universitas Udayana, 5(7), 754-777. Retrieved from https://ojs.unud.ac.id/index.php/eep/article/view/21737

Anggiani, K., \& Azizah, D. F. (2019). Pengaruh Gross Domestic Product (GDP) dan nilai tukar rupiah terhadap volume impor daging sapi di Indonesia tahun 2011-2018. Jurnal Administrasi Bisnis, 73(1), 125-131. Retrieved from http://administrasibisnis.studentjournal.ub.ac.id/index.php/jab/article/view/2910

Beckerman, W. (1956). Distance and the pattern of intra-European trade. Review of Economics and Statistics, 38(1), 31-40. 
Dewi, N A S., (2018). Pengaruh GDP, Inflasi dan exchange rate terhadap ekspor dan impor di Indonesia tahun 1980-2016. Undergraduate Thesis. Universitas Muhammadiyah Surakarta.

Fitzsimons, E., Hogan, V., \& Neary, J. P. (1999). Explaining the volume of North-South trade in Ireland: A gravity model approach. Economic and social review, 30(4).

Ghozali, I. (2016). Aplikasi analisis multivariate dengan program IBM SPSS 23. Semarang: Badan Penerbit Universitas Diponegoro.

Hutzschenreuter, T., Kleindienst, I., \& Lange, S. (2014). Added psychic distance stimuli and MNE performance. Journal of International Management, 20(1), 38-54. https://doi.org/10.1016/i.intman.2013.02.003

Hutzschenreuter, T., Kleindienst, I., \& Lange, S. (2015). The concept of distance in international business research: A review and research agenda. International Journal of Management Reviews, 18(2), 160-179. https://doi.org/10.1111/ijmr.12065

Ichsan, S., Suhadak, S., \& Sulasmiyati, S. (2016). Pengaruh pergerakan nilai tukar Yuan terhadap ekspor dan impor Indonesia (Studi pada Bank Indonesia Periode 2012-2014). Jurnal Administrasi Bisnis, 35(2), 94-103. Retrieved from http://administrasibisnis.studentjournal.ub.ac.id/index.php/jab/article/view/1373

Junaidi, S. K., Sulasmiyati, S., \& Nurlaily, F. (2018). Pengaruh pendapatan nasional, inflasi dan nilai tukar Yuan terhadap impor Indonesia dari China Periode 2010-2017. Jurnal Administrasi Bisnis, 60(2), 111-118. Retrieved from http://administrasibisnis.studentjournal.ub.ac.id/index.php/jab/article/view/2513

Khalimah, K. (2019). Analisis faktor-faktor yang mempengaruhi impor daging sapi di Indonesia tahun 1995-2018. Undergraduate Thesis. Universitas Islam Indonesia.

Krugman, P. R., Obstfeld, M., \& Melitz, M. (2018). International trade: Theory and policy, 11th Edition. Pearson.

Li, K., Song, L. \& Zhao, X. (2008). Component trade and China's global economic integration. Research Paper 2008/101. Helsinki: UNU-WIDER.

Madura, J. (2012). International Financial Management: 11th Edition. USA: South-Western

Mankiw, N. G. (2012). Macroeconomics. Seventh edition. Worth Publisher

Marimoutou, V., Peguin, D., \& Peguin-Feissolle, A., (2010). The" distance-varying" gravity model in international economics: is the distance an obstacle to trade? Retrieved from https://halshs.archives-ouvertes.fr/halshs-00536127/

Mulyadi, M., Saenong, Z., \& Balaka, M. Y., (2017). Pengaruh GDP, ukuran ekonomi, nilai tukar, penduduk dan jarak ekonomi terhadap ekspor Indonesia ke Negara Asean+6: (Pendekatan model gravitasi). JPEP (Jurnal Progres Ekonomi Pembangunan), 2(2). Retrieved from http://ojs.uho.ac.id/index.php/JPEP/article/view/8088

Pakpahan, A.R.S., (2012). Analisis faktor-faktor yang mempengaruhi impor daging sapi di Indonesia. Economics Development Analysis Journal, 1(2). Retrieved from https://journal.unnes.ac.id/sju/index.php/edaj/article/view/471

Prafajarika, S. W., Yulianto, E., Wilopo, W. (2016). Pengaruh nilai tukar, harga dalam negeri dan harga internasional terhadap volume impor daging sapi Indonesia (Survey volume impor komoditi daging sapi Indonesia tahun 2012-2014). Jurnal Administrasi Bisnis, 34(1), 65-72. Retrieved from http://administrasibisnis.studentjournal.ub.ac.id/index.php/jab/article/view/1318

Puspita, K.I. (2018). Pengaruh harga daging sapi impor Australia, kurs US dollar dan penghasilan terhadap value impor daging sapi di Indonesia tahun 1996-2015. Undergraduate Thesis. Univesitas Islam Indonesia.

Salvatore, D. (2014). International economics: Trade and finance. Wiley.

Sukirno, S. (2015). Makroekonomoi: Teori pengantar. Edisi ke-3. Jakarta. Raja Grafindo

Trademap. (2020). List of importing markets from Association of South-East Asian Nations 
Putri, Sulistiyani, \& Indrasari

The Determinants of Meat Import Performance in ASEAN Countries

(ASEAN) for a product exported by Australia Product: 02 Meat and edible meat offal. Retrieved from https://www.trademap.org/

Zickmund, W. G. (2003). Business research method. 7th ed. Mason, OH : Thomson/SouthWestern. 